\title{
Effect of split applications of urea on protein size distribution, physical dough properties, and baking performance of five experimental bread wheat lines
}

\author{
Alma Rosa Islas-Rubio ${ }^{1^{*}}$, Karla Chávez-Quiroz ${ }^{1}$, Francisco Vásquez-Lara ${ }^{1}$, Brenda $^{1}$ \\ Silva-Espinoza ${ }^{1}$, María del Carmen Granados-Nevárez ${ }^{1}$, Humberto Gonzalez-Ríos ${ }^{1}$, Miguel \\ Camacho-Casas $^{2}$
}

\footnotetext{
${ }^{1}$ Departamento de Tecnología de Alimentos de Origen Vegetal, Centro de Investigación en Alimentación y Desarrollo, A.C., Carretera a la Victoria Km 0.6, Hermosillo, Sonora, México; ${ }^{*}$ Corresponding Author: aislas@,ciad.mx

${ }^{2}$ Campo Experimental Valle del Yaqui, Centro de Investigación Regional del Noroeste, Instituto Nacional de Investigaciones Forestales, Agrícolas y Pecuarias, Ciudad Obregón, Sonora, México.
}

Received 18 March 2011; revised 19 May 2011; accepted 9 July 2011.

\section{ABSTRACT}

Five experimental bread wheat lines (BWL) were grown at the Yaqui Valley Experimental Station in Sonora, México during two consecutive growing cycles. The effect of five nitrogen fertilization (NF) treatments on protein size distribution (PSD), physical dough properties (PDP), and baking performance of the BWL was evaluated. Polymeric and monomeric proteins were evaluated by SE-HPLC. PDP were carried out by the National Mixograph and the TA-XT2 Texture Analyzer. Baking performance was evaluated using the straight dough method. Protein content (PC), main protein fractions (glutenins, gliadins, albumins-globulins), and mixograph development time (MDT) were significantly influenced by NF treatment and BWL but not by their interaction. On the other hand, PDP measured by the Kieffer rig, and baking performance were significantly influenced by the main factors (NF and BWL) and their interaction. The amount and timing of fertilizer applied to the BWL modified the PC, PSD, PDP, and bread loaf volume. PDP exhibited a larger variation in comparison to the PSD of glutenins. The split application of $150 \mathrm{~kg}$ of urea/ha (50-50-50) to all BWL showed a better loaf volume response than the same amount of urea applied at sowing (150-0-0). The application of $300 \mathrm{~kg}$ of urea/ha to all BWL, either at sowing or at three split applications of $100 \mathrm{~kg}$ of urea/ha each, resulted in higher flour unextractable polymeric protein (FUPP). On the other hand, the split application of $100-100-100 \mathrm{~kg}$ of urea/ha to three of the BWL represented the higher total unextractable polymeric protein (TUPP). Differences on PC and PSD were reflected on differences on PDP and bread loaf volume observed among the BWL.

Keywords: Wheat; Nitrogen Fertilization; Protein Composition; Dough Properties

\section{INTRODUCTION}

Wheat quality is determined by genetic and environmental factors. These factors affect protein content and composition, therefore gluten functionality. Nitrogen fertilization is an important management practice that influences the amount of protein accumulated in the grain. The amount of the most difficult to extract proteins has been reported to be a major determinant of gluten strength [1-3]. Grain protein composition is one of the most important factors determining the breadmaking quality of wheat flour [4]. Protein accumulation during grain filling has been investigated and found to be influenced by irrigation and fertilizer rate $[5,6]$. Temperature and nitrogen timing have been reported as the main environmental factors leading to variation of amount and size distribution of polymeric protein at grain maturity [7-9]. Differences in amounts of all types of proteins due to temperature have been reported [10]. The influence of nitrogen fertilization on amounts and proportions of different protein types in wheat flours was reported [11]. Also, the effect of sulfur alone or in combination with nitrogen fertilization on commercial-scale quality, mixing requirements, protein composition and dough strength has been investigated $[12,13]$. 
The dependence of various quality parameters on protein composition has been determined [3,14-18]. Relationships reported in these studies are based on physical dough measurements with instruments that require a considerable amount of sample. Few studies have evaluated the relationships of breadmaking performance of wheat flours with rheological measurements at a microscale level [19-21]. The use of small sample sizes and the ability to measure protein composition related to functional properties of wheat flours are required in breeding programs. To our knowledge no report has been made regarding the effect of nitrogen fertilization on protein size distribution, micro-scale physical dough measurements and baking performance of wheat flours. Knowing the response of experimental wheat lines to nitrogen fertilization may help to determine the nitrogen level that results in an improved breadmaking quality. Therefore, the aim of this study was to evaluate the effect of nitrogen fertilization (NF) treatments on protein size distribution, micro-scale physical dough measurements and baking performance of flours from experimental bread wheat lines (BWL).

\section{MATERIALS AND METHODS}

\subsection{Wheat Cultivation}

Five bread wheat lines were grown at the Yaqui Valley Experimental Field in Ciudad Obregon, Sonora, Mexico, during the 2002-2003 and 2003-2004 growing seasons (Table 1). A randomized complete block design was used in planting three replicate plots of each BWL under the following nitrogen (urea) fertilization treatments: no fertilization (0-0-0), application of $150 \mathrm{~kg} / \mathrm{ha}$ at sowing $(150-0-0), 300 \mathrm{~kg} / \mathrm{ha}$ at sowing (300-0-0), and three split-application (at sowing-at the first auxiliary irrigation-at the second auxiliary irrigation) of $150 \mathrm{~kg} / \mathrm{ha}$ (50$50-50)$ and $300 \mathrm{~kg} / \mathrm{ha}$ (100-100-100). Wheat samples from each replicate plot $\left(8 \mathrm{~m}^{2}\right)$ were separately harvested, numbered, bagged and sent to the laboratory for milling and subsequent quality evaluations.

Table 1. Origen of experimental bread wheat lines.

\begin{tabular}{cc}
\hline BWL $^{\mathrm{a}}$ & Pedigree \\
\hline 1 & Vee/Koel/Siren/3/Ariv92 \\
2 & Rayon_F89 \\
3 & Irena/Babax/Pastor \\
4 & Rabe/6/Wrm/4/Fn/3*Th//K58/2*N/3/Aus-6869/5/Pelotas \\
5 & -Arthur/7/2*Rabe/8/Irena \\
& Weebil_35Y \\
\hline
\end{tabular}

${ }^{\mathrm{a}}$ Bread wheat line.

\subsection{Wheat Milling and Quality Testing}

Wheat samples from each replicate plot were tempered (14\% moisture content) overnight and milled in a Brabender Quadrumat Jr. Mill (Hackensack, NJ) as described in Approved Method 26-21A [22]. Milled flours were evaluated for moisture and ash content using Approved Methods 44-19 and 44-08. Protein content (PC) was determined according to the Kjeldahl method, using a factor of 5.7 to calculate protein from nitrogen.

\subsection{Protein Extraction and SE-HPLC}

The total protein (TP) was extracted by sonicating flour $(10 \mathrm{mg}$ ) suspensions in $0.5 \%$ SDS in $0.05 \mathrm{M}$ sodium phosphate buffer $(1 \mathrm{~mL}), \mathrm{pH} 6.9$, for $15 \mathrm{~s}$ at power setting of $\sim 3$ (output 6 Watts) in a membrane Dismembrator (model 100, Fisher Scientific, Pittsburg, PA) using a stepped microtip probe (3 $\mathrm{mm}$ diameter) as described by Batey et al. [23]. The extractable protein (EP) was determined by collecting the supernatant, once the flour suspension in SDS buffer was stirred for 5 min (no sonication). The residue (pellet) from the previous extraction was then sonicated for $25 \mathrm{~s}$ in the buffer $(1 \mathrm{ml})$ to solubilize the remaining protein, that is the unextractable protein (UP). All extracts were filtered $(0.45$ $\mathrm{mm}$ filter), heated at $80^{\circ} \mathrm{C}$ for $2 \mathrm{~min}$ in a water bath and cooled with ice and water prior to injection in a BioSepSEC-S 4000 column (Phenomenex, Torrence, CA). The HPLC profile was divided into peaks 1, 2 and 3 corresponding to polymeric protein (TPP or glutenins), gliadins, and albumins/globulins and the absolute and relative peak areas were recorded. The ratio of EP peak 1 to UP peak 1 or the percentage of UP peak 1 in TP peak 1 (EP peak 1 + UP peak 1), a measure of the relative size distribution of the polymeric protein, was also calculated and reported as total unextractable polymeric protein (TUPP). The percentages of flour polymeric protein (FPP) and flour unextractable polymeric protein (FUPP) were also calculated. All SE-HPLC measurements were made in duplicate and averaged.

\subsection{Physical Dough Properties}

Optimum water absorption and mixing time (MDT) for each flour sample was determined in duplicate by a 10-g mixograph (National Mfg. Co., Lincoln NE). Mixograms were determined using a modified AACC method (54-40A) that included $2 \% \mathrm{NaCl} w / \mathrm{w}$ on flour and MDT was recorded and used to mix the dough for the microscale extension test.

The micro-scale dough extension test reported by Kieffer et al. [19] was carried out in duplicate with the Texture Analyzer (TA.XT2, SMS/Kieffer dough extensibility rig, Stable Micro Systems, Surrey, England). 
Dough was optimally mixed in a 10 -g National mixograph and kept in a proofing chamber for $45 \mathrm{~min}$ at $30^{\circ} \mathrm{C}$ afterwards, dough extensional properties were recorded. Test speed for the micro-scale extension test was 3.3 $\mathrm{mm} / \mathrm{s}$. The maximum force (Rmax) and distance to rupture (Ext) were considered as an indication of dough resistance and extensibility, respectively. The area under the curve, which represents the dough deformation work, was also recorded. For the Kieffer rig extensibility test, the average of at least five measurements was considered a replicate.

\subsection{Baking Test}

All flour samples (35 g, 14\% mb) were mixed with salt (0.53 g), dry yeast $(0.7 \mathrm{~g})$, sugar (2.1 g), shortening $(1.05 \mathrm{~g})$, and water in a $35-\mathrm{g}$ mixograph (National Mfg. Co., Lincoln, NE) and baked according to AACC Method 10 - 10B. Doughs were sheeted with roller gaps of 0.119 " for pre-molding punch, and 0.143 " for 1 st and 2nd punches (M.D. Shogren, personal communication). In this procedure, doughs were placed in 35-g baking pans, proofed for $40 \mathrm{~min}$ at $30 \pm 1{ }^{\circ} \mathrm{C}$ and $94 \% \mathrm{rh}$, and baked for $17 \mathrm{~min}$ at $215^{\circ} \mathrm{C}$. On completion of baking, each loaf was weighed and its volume determined by the rapeseed displacement method. The specific volume of each loaf (BSV) was calculated by dividing the loaf volume (BLV) and weight (BWT). Two loaves of bread were prepared from each flour sample per replicate.

\subsection{Experimental Design and Statistical Analyses}

A randomized complete block design with factorial arranges was used in the experiment. The growing cycle was considered as random effect of the block. BWL (5) and NF treatments (5) were considered as factors and three experimental units by treatment were used. The effects of growing cycle, BWL, NF, and BWL $x$ NF interaction on the response variables at $5 \%$ level $(p<0.05)$ were evaluated by the general linear model procedure with the NCSS statistical package [24]. Three replicates were analyzed for each BWL subjected to each NF treatment. The BWL and NF were considered as fixed effects. When significant effects were found, the mean comparisons were done by the Tukey's multiple range test. Additionally, principal components analysis (PCA) was conducted to obtain a small number of factors that account for most of the variability in the response variables.

\section{RESULTS AND DISCUSION}

\subsection{Flour Quality Testing}

Moisture and ash content of flours (data not shown) ranged between $11.4 \%-13.7 \%$, and $0.37 \%-0.53 \%$, respectively. PC was significantly influenced by the BWL and NF treatment (Table 2). The average PC of the BWL was between $10.4 \%$ and $12.2 \%$ (Table 3). The BWL 1 contained a significantly higher amount of protein than the rest. The lower PC corresponded to BWL 3 and 5. A high availability of nitrogen after anthesis generally leads to a high concentration in the kernel [25], therefore it is worthwhile to know how long it takes for the different BWL to reach maturity. Availability of nitrogen after anthesis is unknown since the amount of nitrogen in the soil previous to sowing was not determined in this study. Furthermore, nitrogen applied in the form of urea, which was the case, is susceptible to loss through drainage. The application of nitrogen to all the BWL had a significant effect on PC. Depending on the NF treatment, the average PC fluctuated between 9.1 and $12.1 \%$ (Table 3); the lower PC value corresponded to the unfertilized BWL (0-0-0). In general, the PC increased as the amount of nitrogen applied increased as it was previously reported [20]. The application of $300 \mathrm{~kg}$ of urea/ha resulted in higher PC than the application of $150 \mathrm{~kg}$ of urea/ha $(12 \%-12.1 \%$ vs. $10.7 \%-11 \%)$. This finding is in agreement with other authors $[11,26]$. It has been demonstrated that management of nitrogen fertilization can increase grain protein in wheat and the increase of protein caused by higher levels of nitrogen fertilization is strongly dependent on the genotype.

\subsection{Protein Composition and Size Distribution}

The interaction of BWL and NF treatment was not significant for PC, TPP (glutenins), gliadins, and albu-

Table 2. Effect of bread wheat line, nitrogen fertilization treatment and its interaction on protein composition, rheological measurements and bread loaf volume of flours ${ }^{\mathrm{a}}$.

\begin{tabular}{|c|c|c|c|c|c|c|c|c|c|}
\hline Source & PC & TPP & Gliad & TUPP & MDT & Rmax & Ext & Area & BLV \\
\hline BWL & $35.2^{* * *}$ & $3.5^{* *}$ & $35.3^{* * *}$ & $5.3^{* * *}$ & $10.2^{* * *}$ & $6.7^{* * *}$ & $8.3^{* * *}$ & $6.2^{* *}$ & $30.5^{* * *}$ \\
\hline NFT & $93.7^{* * *}$ & $2.9^{*}$ & $178.6^{* * *}$ & $52.7^{* * *}$ & $30.8^{* * *}$ & $12.5^{* * *}$ & $5.1^{* * *}$ & $10.7^{* * *}$ & $36.2^{* * *}$ \\
\hline BWL*NFT & 0.8 & 1.2 & 0.9 & $3.7^{* * *}$ & 1.2 & $2.5^{* *}$ & $1.8^{*}$ & $2.2^{* *}$ & $3.0^{* * *}$ \\
\hline
\end{tabular}

${ }^{\mathrm{a}} \mathrm{F}$-values and level of significance $\left({ }^{*},{ }^{* *}\right.$, and ${ }^{* * *}$ represent $p<0.05, p<0.01$, and $p<0.0001$, respectively.). BWL $=$ bread wheat line, NFT $=$ nitrogen fertilization treatment, $\mathrm{PC}=$ protein content, TPP $=$ total polymeric protein or glutenins, Gliad $=$ gliadins, TUPP $=$ total unextractable polymeric protein, $\mathrm{MDT}=$ Mixograph development time, $\mathrm{Rmax}=$ dough maximum resistance, Ext $=$ extensibility, Area $=$ dough deformation work, $\mathrm{BLV}=\mathrm{bread}$ loaf volume. 
Table 3. Mixograph development time, protein content and composition of flours recorded in every bread wheat line as well as in every nitrogen fertilization treatment, after two growing seasons ${ }^{\mathrm{a}}$.

\begin{tabular}{|c|c|c|c|c|c|c|c|}
\hline Main & Effect & MDT (min) & Protein (\%) & ТРP (\%) & Gliadins (\%) & $\mathrm{Alb}+$ Glob $(\%)$ & FPP (\%) \\
\hline \multirow[t]{5}{*}{ BWL: } & 1 & $4.7 \pm 0.2 \mathrm{c}$ & $12.2 \pm 0.3 a$ & $42.9 \pm 0.4 \mathrm{ab}$ & $44.1 \pm 0.4 a$ & $13.1 \pm 0.4 c$ & $5.2 \pm 0.1 \mathrm{a}$ \\
\hline & 2 & $5.3 \pm 0.2 \mathrm{ab}$ & $10.9 \pm 0.3 b c$ & $43.8 \pm 0.3 a$ & $42.5 \pm 0.4 b$ & $13.7 \pm 0.4 b c$ & $4.7 \pm 0.1 b$ \\
\hline & 3 & $5.1 \pm 0.2 b$ & $10.4 \pm 0.2 \mathrm{c}$ & $43.0 \pm 0.4 \mathrm{ab}$ & $41.8 \pm 0.4 c$ & $15.3 \pm 0.6 \mathrm{a}$ & $4.5 \pm 0.1 \mathrm{c}$ \\
\hline & 4 & $5.0 \pm 0.2 b c$ & $11.0 \pm 0.2 b$ & $43.6 \pm 0.3 a$ & $41.4 \pm 0.4 c$ & $15.0 \pm 0.4 \mathrm{ab}$ & $4.8 \pm 0.1 b$ \\
\hline & 5 & $5.5 \pm 0.2 \mathrm{a}$ & $10.4 \pm 0.2 \mathrm{c}$ & $42.3 \pm 0.6 b$ & $43.0 \pm 0.5 b$ & $14.6 \pm 0.7 \mathrm{ab}$ & $4.4 \pm 0.1 \mathrm{c}$ \\
\hline \multirow{4}{*}{ NFT: } & $150-0-0$ & $6.0 \pm 0.2 \mathrm{a}$ & $11.0 \pm 0.2 b$ & $43.7 \pm 0.3 \mathrm{a}$ & $42.3 \pm 0.3 b$ & $14.0 \pm 0.2 b$ & $4.7 \pm 0.1 b$ \\
\hline & $300-0-0$ & $4.9 \pm 0.1 b c$ & $12.1 \pm 0.2 \mathrm{a}$ & $43.0 \pm 0.2 \mathrm{ab}$ & $44.3 \pm 0.2 \mathrm{a}$ & $12.8 \pm 0.2 \mathrm{c}$ & $5.2 \pm 0.1 \mathrm{a}$ \\
\hline & $50-50-50$ & $5.1 \pm 0.2 b$ & $10.7 \pm 0.1 b$ & $43.5 \pm 0.2 \mathrm{ab}$ & $42.7 \pm 0.2 b$ & $13.7 \pm 0.3 b$ & $4.7 \pm 0.1 b$ \\
\hline & $100-100-100$ & $4.6 \pm 0.1 \mathrm{c}$ & $12.0 \pm 0.1 \mathrm{a}$ & $42.4 \pm 0.3 b$ & $44.6 \pm 0.3 \mathrm{a}$ & $13.0 \pm 0.3 \mathrm{c}$ & $5.2 \pm 0.1 \mathrm{a}$ \\
\hline
\end{tabular}

${ }^{a}$ Values represent the mean $(n=30) \pm$ standard error. Within a column and the same main effect, values followed by the same letter are not significantly different at $p=0.05$ level. BWL $=$ bread wheat line, NFT $=$ nitrogen fertilization treatment with urea (at sowing-first auxiliary irrigation-second auxiliary irrigation), $\mathrm{MDT}=$ mixograph development time, $\mathrm{TPP}=$ total polymeric protein, $\mathrm{Alb}+\mathrm{Glob}=$ albumins and globulins, $\mathrm{FPP}=$ polymeric protein in the flour, $\mathrm{FUPP}=\mathrm{unex}-$ tractable polymeric protein in the flour.

mins/globulins. The mean values of these parameters for each BWL and NF treatment are shown in Table 3. The averages of the percentage of polymeric protein (glutenins), gliadins, and albumins/globulins among the BWL varied from $42.3 \%$ to $43.8 \%, 41.4 \%$ to $44.1 \%$, and $13.1 \%$ to $15.3 \%$, respectively. Depending on the NF treatment, these main protein fractions varied between $42.4 \%$ and $43.7 \%$ (glutenins), $38.7 \%$ and $44.6 \%$ (gliadins), and $12.8 \%$ to $18.2 \%$ (albumins/globulins). The percentage increase of gliadins was higher than that of glutenins; this means that the ratio gliadins/glutenins was increased by a high nitrogen level which is in agreement with other studies [11,17,27-29]. A significant reduction in the amount of albumins/globulins was observed when urea was applied to all BWL (18.2\% vs. $12.8 \%-14 \%$ ). It has been reported that this protein group is scarcely influenced by nitrogen nutrition $[11,14,30,31]$ and it does not play an important role in breadmaking quality of wheat flours. [32-34].

The three split-application of 300 or $150 \mathrm{~kg}$ of urea/ha to all BWL resulted in a slight decrease on the polymeric proteins in comparison with the same amount of urea applied at sowing, with a concomitant increase in gliadins. A higher availability of nitrogen has been reported to increase gliadins synthesis and decrease of glutenins [17]. Most studies described in the literature report that the gliadins/glutenins ratio was significantly increased by a high nitrogen level $[11,17,29]$. This could explain the variation in the amounts of glutenins and gliadins observed in this study.

The FPP was not affected by the interaction of BWL and NF treatment, but it was by BWL and NF treatment. The averages of FPP among the different BWL and NF treatments are shown in Table 3. The BWL 1 had a significantly higher percentage of FPP, whereas BWL 5 and 3 showed the lowest percentage $(4.4 \%$ and $4.5 \%$, respectively). Similar values of FPP were observed for BWL 2 and 4. Differences in the amounts of glutenins and PC between these BWL are responsible for these FPP values.

NF treatment, BWL, and their interactions significantly influenced the TUPP (Table 2) and FUPP (Figure 1(e)). Depending on the BWL and the amount and timing of urea application, the averages of the TUPP were between $35.7 \%$ and $53.7 \%$ (Figure 1(d)), whereas those of the FUPP were between $1.28 \%$ and $2.91 \%$. The split application of 100-100-100 kg of urea/ha to each BWL rendered the higher TUPP, whereas the application of $50-50-50 \mathrm{~kg}$ of urea to BWL 1, 2 and 5 produced the lower TUPP values for these BWL. On the other hand, the lower TUPP values of BWL 3 and 4 were obtained when $150 \mathrm{~kg}$ of urea were applied at sowing. This protein fraction was suggested as an effective evaluation parameter in wheat breeding programs targeting quality [35]. The FUPP increased with the application of urea to each BWL. The BWL responded differently to the amount and timing of urea application. The amount of $300 \mathrm{~kg}$ of urea, either at a single application at sowing (to BWL 1, 2 and 5) or at three split applications (100-100-100) (to BWL 3 and 4) gave the higher FUPP. Four of the BWL showed the lower FUPP when the split application of 50-50-50 kg of urea was used.

The amount and timing of urea application had a significant effect on protein size distribution of most BWL. Small differences in TUPP were observed when $150 \mathrm{~kg}$ of urea/ha (150-0-0 or 50-50-50) were applied to all BWL. Higher values of FPP and FUPP were observed when $300 \mathrm{~kg}$ of urea/ha were applied to all BWL, either at sowing (300-0-0) or at split applications (100-100$100)$, but there was no significant difference between these two NF treatments. Gupta et al. [3,17] found a stronger relationship between the polymeric protein content of flours and Rmax values of dough rested for 45 min than with the total protein content in flours. Other authors [16] reported that the glutenin macropolymer 


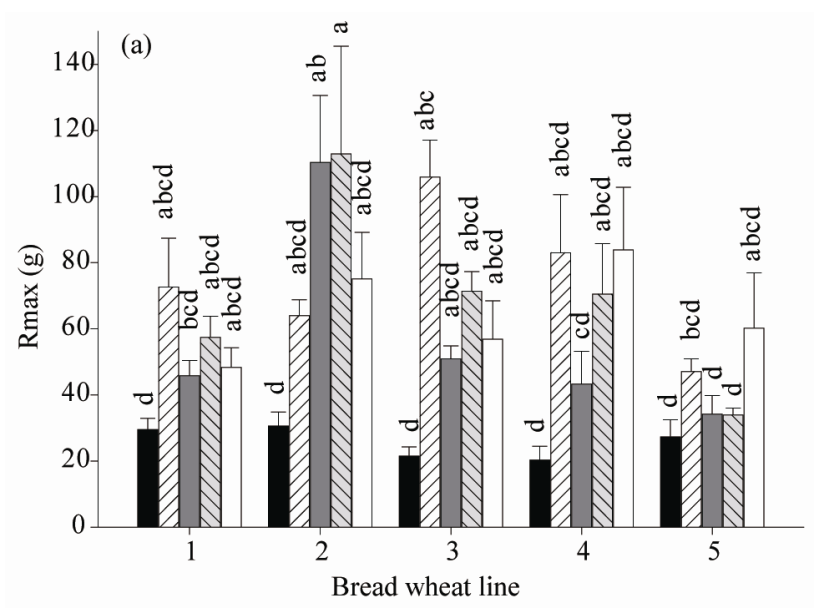

(a)

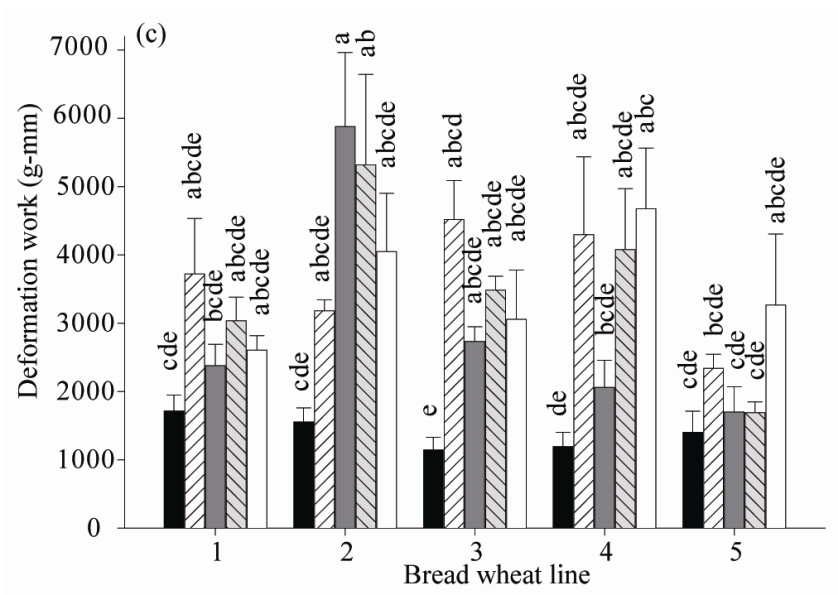

(c)

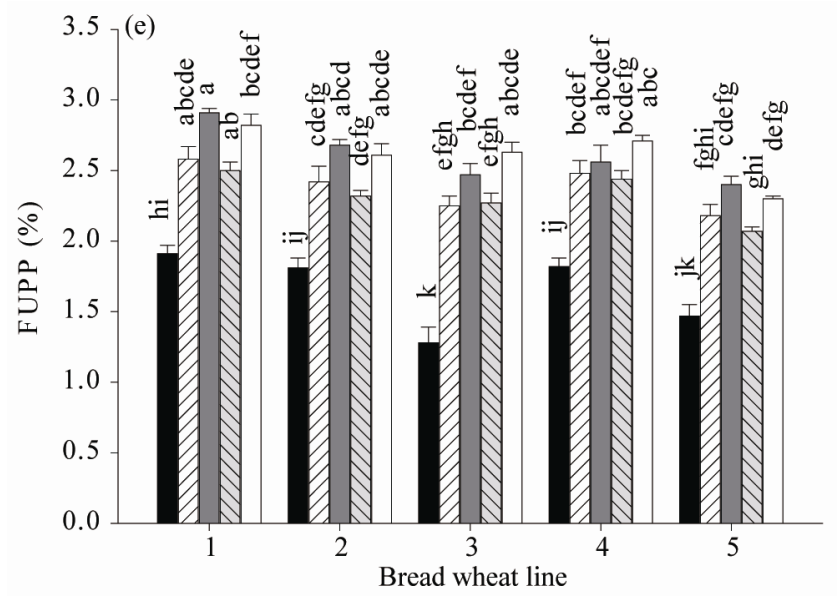

(e)

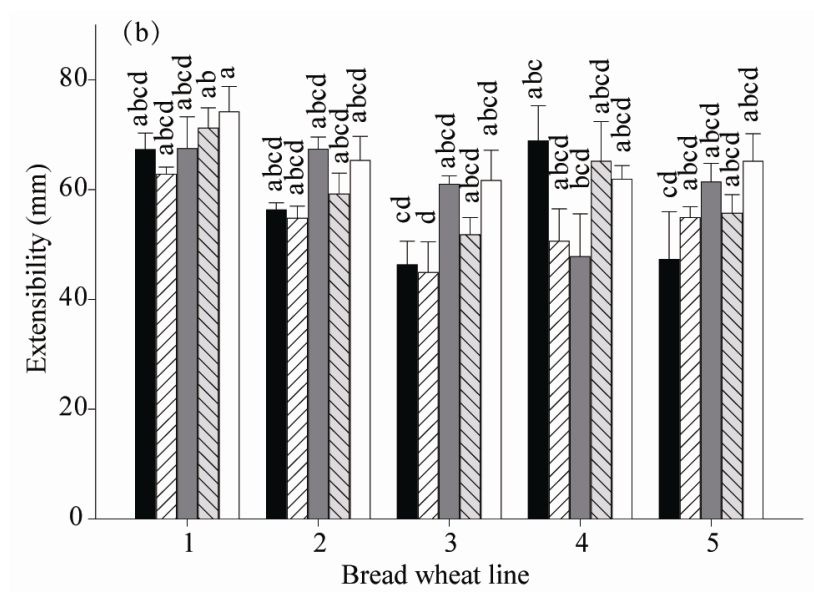

(b)

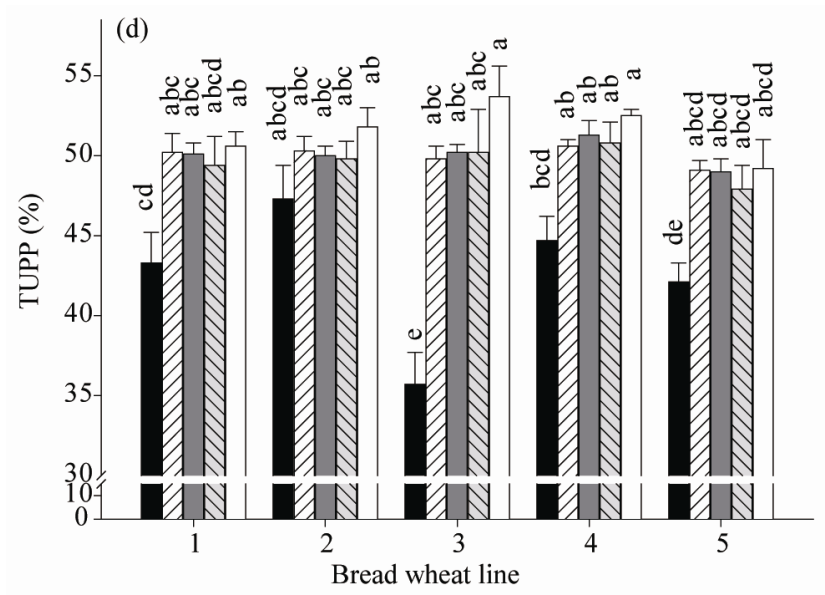

(d)

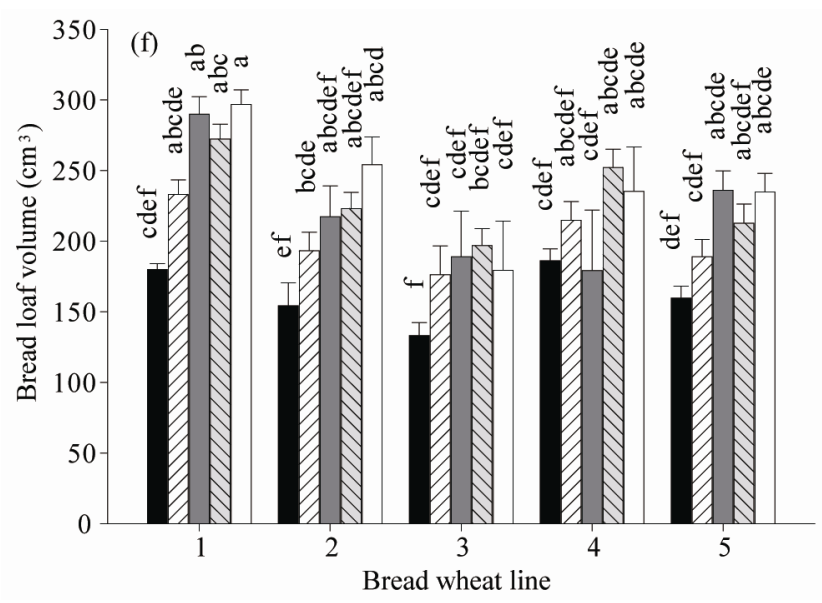

(f)

Figure 1. Effect of nitrogen fertilization treatments on dough maximum resistance (a), extensibility (b), deformation work (c), total unextractable polymeric protein (d), flour unextractable polymeric protein (e), and bread loaf volume (f) of the experimental bread wheat lines. Data are means \pm standard error for $n=3$ replicates. Different lowercase letters on the top of bars indicate significant differences $(p<0.05)$. Nitrogen fertilization treatments (kg of urea/ha): 0-0-0( $)$, 150-0-0 ( $\square / \lambda), 300-0-0(\square), 50-50-50$ $(\triangle \backslash), 100-100-100(\square)$. 
(GMP) content of dough after 45 min rest was more strongly related to Rmax, whereas the GMP content of flour was strongly related to extensibility and loaf volume. Larger molecules form stronger network which stands a higher force before rupturing. The application of urea to all BWL increased the TUPP and FUPP (Figures 1(d) and (e)). An increase in TUPP has been reported to shift the molecular weigth distribution of the glutenin to higher molecular weigths [18] and this has also contributed, in some cases, to decreased extensibility. The extensional properties of doughs in those studies were measured with the Brabender Extensigraph.

\subsection{Physical Dough Properties}

The minimum-maximum water absorption and MDT values were $57.7 \%-64.1 \%$ and $4.3-6.3 \mathrm{~min}$, respectively. The application of urea differently affected the MDT of the flours (Table 3). Longer MDT was observed in flours from BWL 5, followed by BWL 2. An extended MDT is not desirable as this is an added cost to baking. A maximum MDT of $4.5 \mathrm{~min}$ is desirable in the bread wheat breeding program in Mexico. The proportion of polymeric protein and not the total amount in the grain or flour might be responsible for the longer MDT [15, $16]$.

Measurements reported in this study corresponded to the $45 \mathrm{~min}$ rest dough. The extension parameters obtained at $45 \mathrm{~min}$ of rest time are more reproducible compared with longer resting time [36]. The application of urea differently affected the extensional properties of the flours. Rmax (Figure 1(a)) ranged from 20.3 to $112.9 \mathrm{~g}$. On the other hand, dough Ext (Figure 1(b)) varied between 44.9 and $74.2 \mathrm{~mm}$. The deformation work or area under the TA-XT2 curve (Figure 1(c)) varied between 1,193.6 and 5,879.6 g-mm. The Rmax of all BWL increased with the application of urea and the increase depended on the BWL and the amount and timing of the application. The higher increases in Rmax were observed with BWL 2 and 3. An amount of 300 or $150 \mathrm{~kg}$ of urea/ha applied to BWL 2 (300-0-0 or 50-50-50) and BWL 4 (100-100-100 or 150-0-0) resulted in doughs with similar strength (Rmax $110-113 \mathrm{~g}$ and $83-84 \mathrm{~g}$, corresponding to BWL 2 and 4, respectively). The strongest dough obtained from BWL 1 corresponded to the application of $150 \mathrm{~kg}$ of urea/ha at sowing, whereas the application of 100-100-100 kg of urea/ha to BWL 5 produced the strongest dough for this BWL. In addition to strength, breadmaking requires dough that is extensible, allowing ease of handling and the rising of bread to form a large loaf [37]. Regarding to Ext, the application of $150 \mathrm{~kg}$ of urea at sowing (150-0-0) to three of the BWL resulted in a slight decrease in dough Ext as compared with the unfertilized counterparts. BWL 4 showed a reduction in dough Ext with any of the applications of urea. The opposite happened with BWL 5. The more extensible doughs from BWL 1, 3 and 5 corresponded to the NF treatment of $100-100-100 \mathrm{~kg}$ of urea/ha. The balance of dough strength and extensibility are believed to be the most important factors governing the suitability of a flour to make good bread [38].

As expected, the application of urea to all BWL made their flours stronger (Figure 1). The doughs that required more work to be deformed were those obtained from flours of the BWL 2 (300-0-0 NF treatment), BWL 4 (100-100-100), BWL 3 (150-0-0), and BWL 1 (150-0$0)$. The deformation work represented by the area under the curve described by the texture analyzer TA-XT2 resembles that described by the Brabender Extensigraph, but the difference between these curves is that the texture analyzer curve is stopped once the dough ruptures, in other words, it last to the peak which corresponds to the maximum resistance. This area is not comparable to that obtained by the Brabender Extensigraph (W value). The value of the area under the curve described by the texture analyzer was not a good predictor of breadmaking quality among wheat flours, as it is the $\mathrm{W}$ value of the Brabender Extensigram. It seems to be more important the shape of the curve to explain differences in breadmaking quality. Extensible doughs are preferred for breadmaking, but not too weak neither too strong. In the case of BWL 2, two of the NF treatments produced a very strong dough (110.3 and $112.9 \mathrm{~g}$ ) with good extensibility $(59.2$ and $67.4 \mathrm{~mm})$, whereas the dough obtained from the same BWL when 100-100-100 kg of urea/ha were applied to it presented a more balanced gluten $(\mathrm{Rmax}=75.1 \mathrm{~g}$ and Ext $=65.3 \mathrm{~mm})$, which resulted in a higher loaf volume $\left(254.2 \mathrm{~cm}^{3}\right)$. For BWL 4, it appears that the application of 50-50-50 kg of urea/ha produced the best balance between Rmax and Ext (71.4 g and 65.2 $\mathrm{mm})$. Based on the dough Ext values obtained from the set of samples used in this study, it appears that Rmax values higher than $80 \mathrm{~g}$ did not favor the gluten balance; therefore, increases in loaf volume were not expected for those BWL subjected to the NF treatments that resulted in very strong doughs. In general, BWL 4 presented the strongest dough whereas BWL 5 produced the weakest one. Bangur et al. [15] and Weegels et al. [16] found that dough strength is related to the fraction of polymeric protein with the highest molecular weight. Similarly, other authors $[3,39]$ reported that attributes related to dough strength increase with a higher proportion of very large glutenin polymers. Also, Extensigram height (Rmax) positively correlated to the percentage of protein only extractable into SDS-buffer after sonication [3]. Therefore, the observed differences in dough strength can be attributed, in part, to differences in TUPP, FPP, and 
FUPP.

\subsection{Loaf Volume}

Bread loaf volume varied between 133.1 and 296.8 $\mathrm{cm}^{3}$. In general, higher loaf volumes were obtained when urea was applied to all BWL and different responses among BWL were observed (Figure 1(f)). For BWL 1 and 5, the application of $300 \mathrm{~kg}$ urea/ha, either at sowing or at three split applications of $100 \mathrm{~kg}$ of urea each, resulted in higher loaf volume $\left(\sim 300 \mathrm{~cm}^{3}\right.$ for BWL 1 and $\sim 240 \mathrm{~cm}^{3}$ for BWL 5). On the other hand, BWL 2 showed the highest loaf volume when three split applications of $100 \mathrm{~kg}$ urea/ha were used. The lower increase in loaf volume corresponded to BWL 3. The breadmaking quality of this BWL can be marginally improved through nitrogen (urea) management. None of the flours from BWL 3 produced loaves of bread with a volume higher than $200 \mathrm{~cm}^{3}$. The lowest loaf volumes of breads made from this BWL could be due to the limited response in PC (it showed the lowest average) to the application of urea. High PC has been associated with high loaf volume [40-42]. For BWL 3 and 4, the split application of $50-50-50 \mathrm{~kg}$ of urea/ha produced the higher loaf volume. The split application of $150 \mathrm{~kg}$ of urea/ha (5050-50) to all BWL resulted in significantly higher loaf volume than the application of $150 \mathrm{~kg} / \mathrm{ha}$ at sowing. When $300 \mathrm{~kg}$ of urea were applied to BWL 1, 3, and 5, either as split application (100-100-100) or $300 \mathrm{~kg} / \mathrm{ha}$ at sowing, no significant differences in bread loaf volume were observed.

The differences in bread loaf volume among BWL might be ascribed, in part, to the potential of each BWL to synthesize protein and the availability of nitrogen during grain filling. Also, these differences can be explained by looking at differences in physical dough properties. It is well known that flours of good breadmaking quality are characterized by a suitable balance between dough resistance to extension (Rmax) and extensibility (Ext) [43]. In general, BWL-5 produced loaves of bread with the lower volumes and its doughs showed low resistance to extension (27.3 to $60.2 \mathrm{~g}$ ) and intermediate extensibility (average $56.9 \mathrm{~mm}$ ), which confers a lower strength to the dough. Both, Rmax and Ext, are important for retaining the gas produced during fermentation. An excessive resistance to extension may result in lower loaf volume. Dough with poor extensibility is not desirable for breadmaking. Previous studies showed that total glutenin content in flour (TPP) largely affected the dough strength [44,45], but this measure is not as widely applicable as a selection criterion as TUPP and \% UPP [3].

It is worthwhile to mention that, in this work, the dough extensional properties were measured with the
Texture Analyzer TA-XT2 using a smaller amount of flour $(10 \mathrm{~g})$ than the amount required for the Brabender Extensigraph. In addition, the standardized baking procedure using $35 \mathrm{~g}$ of flour as well as the small amount of sample required for SE-HPLC analyses $(<1 \mathrm{mg})$ make this methodology suitable for wheat breeding programs where the amount of sample is limited. A total of $130 \mathrm{~g}$ of flour is enough to run duplicates for most measurements, except protein, ash, and moisture analyses which are run in triplicate. This methodology was used in a previous study [21] and the generated data used to predict loaf volume. Most of the variation in bread volume (87\%) was explained by PC, MDT, Mixograph water absorption, dough deformation work (area under the TA-XT2 curve), and TUPP.

\subsection{Principal Component Analysis}

Factor analysis using principal components (PCA) resulted in the extraction of four factors that had Eigen values $\geq 1$ and together accounted for more than $80 \%$ of the variability in the fourteen response variables studied (Table 4). The first factor (PC1) has an Eigen value of 5.88 , that is, it absorbs the variability of almost 6 variables, showing a contribution of $42 \%$ of the variance. The PC2 has an Eigen value of 2.49 and an explained contribution of $17.8 \%$. The PC 3 and PC4 showed Eigen values of 1.77 and 1.06, respectively. Analyzing the composition and contribution (Eigen values) of the original variables within each selected principal component (Table 5), it is observed that PC1 is an average of all variables, even if a greater negative contribution of the variables PC, BLV, BSV, gliadins, FPP, TUPP, and FUPP is shown. Therefore, this suggests that PC1 is related to the indicative variables of protein quality of the wheat flours. The influence of TPP, MDT, and BWT was small, since their loadings for PC1 is close to null. The PC2 can be described like a contrast of the variables, where TPP, Area, and Rmax participate with positive charge and MDT, BLV, BSV, and albumins-globulins with negative charge, which suggests that the dimensionality of $\mathrm{PC} 2$ is related to the rheological properties of the flours. In PC3, the Eigen vectors indicate a greater contribution of Rmax, dough deformation work (area), and MDT with negative charges, therefore, the relationship of PC3 with the technological characteristics of the wheat flours. In PC4, the Eigen vectors indicate a close relationship between PC and gliadins. The influence of Ext is large, whereas that of albumins-globulins is small. TUPP is more closely related to BLV than dough Ext.

\section{CONCLUSIONS}

The application of urea to all BWL increased PC, the 
Table 4. Eigen values, contribution of individual and cumulative variance of the principal components to the total variability obtained by the principal component analysis in the fourteen response variables studied.

\begin{tabular}{cccc}
\hline $\begin{array}{c}\text { Component } \\
\text { number }\end{array}$ & Eigen value & $\begin{array}{c}\text { Individual variance } \\
(\%)\end{array}$ & $\begin{array}{c}\text { Cumulative } \\
\text { variance }(\%)\end{array}$ \\
\hline 1 & 5.880 & 42.00 & 42.00 \\
2 & 2.493 & 17.81 & 59.82 \\
3 & 1.776 & 12.69 & 72.51 \\
4 & 1.067 & 7.62 & 80.13 \\
5 & 0.957 & 6.84 & 86.97 \\
6 & 0.788 & 5.63 & 92.61 \\
7 & 0.463 & 3.31 & 95.91 \\
8 & 0.279 & 2.00 & 97.91 \\
9 & 0.247 & 1.76 & 99.68 \\
10 & 0.019 & 0.14 & 99.81 \\
11 & 0.013 & 0.10 & 99.91 \\
12 & 0.008 & 0.06 & 99.97 \\
13 & 0.002 & 0.02 & 99.99 \\
14 & 0.000 & 0.01 & 100.0 \\
\hline
\end{tabular}

Table 5. Contribution (Eigen vectors) of the original variables in the selected principal components.

\begin{tabular}{ccccc}
\hline & \multicolumn{4}{c}{ Principal Components } \\
Variable ${ }^{\mathrm{a}}$ & PC1 & PC2 & PC3 & PC4 \\
& -0.365 & -0.105 & 0.103 & -0.255 \\
PC & 0.023 & -0.397 & -0.389 & -0.009 \\
MDT & 0.088 & -0.184 & 0.178 & 0.469 \\
BLWT & -0.301 & -0.351 & 0.003 & 0.214 \\
BLV & -0.308 & -0.326 & -0.016 & 0.158 \\
BSV & -0.164 & 0.274 & -0.570 & 0.111 \\
Rmax & -0.204 & -0.024 & 0.245 & 0.599 \\
Ext & -0.184 & 0.248 & -0.548 & 0.197 \\
Area & -0.024 & 0.534 & 0.194 & 0.224 \\
TPP & -0.342 & -0.099 & 0.036 & -0.308 \\
Gliadins & 0.291 & -0.351 & -0.199 & 0.050 \\
Alb-glob & -0.365 & 0.088 & 0.167 & -0.200 \\
FPP & -0.286 & 0.023 & -0.105 & 0.201 \\
TUPP & -0.387 & 0.032 & 0.030 & -0.064 \\
FUPP & &
\end{tabular}

${ }^{\mathrm{a}} \mathrm{PC}=$ protein content, $\mathrm{MDT}=$ mixograph development time, BLWT $=$ bread loaf weigth, $\mathrm{BLV}=$ bread loaf volume, $\mathrm{BSV}=$ bread specific volume, $\mathrm{Rmax}=$ maximum resistance, $\mathrm{Ext}=$ extensibility, Area $=$ deformation work, $\mathrm{TPP}=$ total polymeric protein, Alb-glob $=$ albumins-globulins, $\mathrm{FPP}=$ flour polymeric protein, TUPP $=$ total unextractable polymeric protein, FUPP $=$ flour unextractable polymeric protein.

ratio gliadin to glutenin, dough strength (Rmax and deformation work), TUPP, and FUPP of the flours. The increase depended on the BWL and the amount and timing of the application. Higher bread loaf volumes were obtained when urea was applied to all BWL and different responses among BWL were observed. For BWL 1 and 5 , the application of $300 \mathrm{~kg}$ of urea/ha, either at sowing or at three split applications of $100 \mathrm{~kg}$ each, resulted in higher loaf volume. In the case of BWL 2, the highest loaf volume was obtained when three split applications of $100 \mathrm{~kg}$ of urea/ha were used. For BWL 3 and 4 , the split application of $50-50-50 \mathrm{~kg}$ of urea/ha produced the higher loaf volume. Even other environmental factors also exert their effect, it is possible to change the protein composition of the flours and en- hance the balance between dough Rmax and Ext in order to improve the breadmaking quality through the management of urea.

\section{ACKNOWLEDGEMENTS}

We thank the National Council for Science and Technology of Mexico (CONACYT) for funding this research (Project 40239-Z) and providing scholarships for participating students. We also thank all members of the Yaqui Valley Experiment Station who had to do with the field and laboratory work necessary to provide us the flour samples. We would like to acknowledge the editorial assistance of Dr. Finlay MacRitchie as well as the technical assistance provided by Jorge Mercado-Ruiz.

\section{REFERENCES}

[1] Bietz, J.A. and Wall, J.S. (1975) The effect of various extractants on the subunit composition and associations of wheat glutenin. Cereal Chemistry, 52, 145-155.

[2] Huebner, F.R. and Wall, J.S. (1976) Fractionation and quantitative differences of glutenin from wheat varieties varying in baking quality. Cereal Chemistry, 53, 258269.

[3] Gupta, R.B., Khan, K. and MacRitchie, F. (1993) Biochemical basis of flour properties in bread wheats. I. Effects of variation in quantity and size distribution of polymeric protein. Journal of Cereal Science, 18, 23-41. doi.org/10.1006/jcrs.1993.1031

[4] Wall, J.S. (1979) The role of wheat proteins in determining baking quality. In: Laidman, D.L. and Wyn-Jones, R.G., Eds., Recent Advances in the Biochemistry of Cereals, Academy, London, 275-311.

[5] Panozzo, J.F., Eagles, H.A. and Wootton, M. (2001) Changes in protein composition during grain development in wheat. Australian Journal of Agricultural Research, 52, 485-493. doi:10.1071/AR00101

[6] Altenbach, S.B., DuPont, F.M., Kothari, K.M., Chan, R., Johnson, E.L. and Lieu, D. (2003) Temperature, water and fertilizer influence the timing of key events during grain development in USA spring wheat. Journal of $\mathrm{Ce}$ real Science, 37, 9-20. doi:10.1006/jcrs.2002.0483

[7] Johansson, E., Nilsson, H., Mazhar, H., Skerrit, J., MacRitchie, F. and Svensson, G. (2002) Seasonal effects on storage proteins and gluten strength in four Swedish wheat cultivars. Journal of Science Food and Agriculture, 82, 1305-1311. doi:10.1002/jsfa.1185

[8] Johansson, E. and Svensson, G. (1998) Variation in bread-making quality: Effects of wheater parameters on protein concentration and quality in some Swedish wheat cultivars grown during the period 1975-1996. Journal of Science Food and Agriculture, 78, 109-118. doi:10.1002/(SICI)1097-0010(199809)78:1<109::AID-JS FA92>3.0.CO;2-0

[9] Johansson, E., Prieto-Linde, M.L. and Svensson, G. (2004) Influence of nitrogen application rate and timing on grain protein composition and gluten strength in Swedish wheat cultivars. Journal of Plant Nutrition Soil Science, 167, 345-350. doi:10.1002/jpln.200320332

[10] Johansson, E., Kuktaite, R., Anderson, A. and Prieto- 
Linde, M.L. (2005) Protein polymer build-up during wheat grain development: Influences of temperature and nitrogen timing. Journal of Science Food and Agriculture, 85, 473-479. doi:10.1002/jsfa.2006

[11] Wieser, H. and Seilmeier, W. (1998) The influence of nitrogen fertilization on quantities and proportions of different protein types in wheat flour. Journal of Science Food and Agriculture, 76, 49-55. doi: 10.1002/(SICI)1097-0010(199801)76:1<49::AID-JS FA950>3.0.CO;2-2

[12] Wooding, A.R., Kavale, S., Wilson, A.J. and Stoddard, F.L. (2000) Effects of nitrogen and sulfur fertilization on commercial-scale wheat quality and mixing requirements. Cereal Chemistry, 77, 791-797. doi:10.1094/CCHEM.2000.77.6.791

[13] Wooding, A.R., Kavale, S., MacRitchie, F. Stoddard, F.L. (2000) Effects of nitrogen and sulfur fertilizer on protein composition, mixing requirements, and dough strength of four wheat cultivars. Cereal Chemistry, 77, 798-807. doi:10.1094/CCHEM.2000.77.6.798

[14] Cuniberti, M.B., Roth, M.R. and MacRitchie, F. (2003) Protein composition-functionality relationships of a set of Argentinean wheats. Cereal Chemistry, 80, 132-134. doi:10.1094/CCHEM.2003.80.2.132

[15] Bangur, R., Batey, I.L., McKenzie, E. and MacRitchie, F. (1996) Dependence of extensigraph parameters on wheat protein composition measured by SE-HPLC. Journal of Cereal Science, 25, 237-241. doi:10.1006/jcrs.1996.0098

[16] Weegels, P.L., Hammer, R.J. and Schofield, J.D. (1996) Functional properties of wheat glutenin. Journal of $\mathrm{Ce}$ real Science, 23, 1-18. doi:10.1006/jcrs.1996.0001

[17] Gupta, R.B., Batey, I.L. and MacRitchie, F. (1992) Relationships between protein composition and functional properties of wheat flours. Cereal Chemistry, 69, 125131.

[18] Gupta, R.B., Paul, J.G., Cornish, G.B., Palmer, G.A., Bekes, F. and Rathjen, A.J. (1994) Allelic variation at glutenin subunit and gliadin loci, Glu-1, Glu-3, and Gli-1, of common wheats. I. Its additive and interaction effects on dough properties. Journal of Cereal Science, 19, 9-17. doi:10.1006/jcrs.1994.1003

[19] Kieffer, R., Wieser, H., Henderson, M.H. and Graveland, A. (1998) Correlations of the breadmaking performance of wheat flour with rheological measurements on a micro-scale. Journal of Cereal Science, 27, 53-60. doi:10.1006/jcrs.1997.0136

[20] Uhlen, A.K., Sahlstrom, S., Magnus, E.M., Faergestad, E.M., Dieseth, J.A. and Ringlund, K. (2004) Influence of genotype and protein content on the baking quality of hearth bread. Journal of Science Food and Agriculture, 84, 887-894. doi:10.1002/jsfa. 1797

[21] Islas-Rubio, A.R., MacRitchie, F., Gandikota, S. and Hou, G. (2005) Relaciones de la composición proteínica y mediciones reológicas en masa con la calidad panadera de harinas de trigo. Revista Fitotecnia Mexicana, 28, 243-251.

[22] AACC International (2000) Approved methods of the American Association of Cereal Chemists, 10th Edition, Methods 10-10B, 26-21A, 44-19, 44-08, and 54-40A. The American Association of Cereal Chemists, St. Paul.

[23] Batey, I.L., Gupta, R.B. and MacRitchie, F. (1991) Use of size-exclusion high-performance liquid chromatography in the study of wheat flour proteins: An improved chromatographic procedure. Cereal Chemistry, 68, 207209.

[24] NCSS (2007) Number Cruncher Statistical System for Windows. Kaysville, Utah.

[25] Mitra, R. and Bhatia, C.R. (1973) Studies on protein biosynthesis in developing wheat kernels. Nuclear techniques for seed protein improvement. IAEA, Vienna.

[26] Kelley, K.W. (1995) Rate and time of nitrogen application for wheat following different crops. Journal of Production Agriculture, 8, 339-345.

[27] Prugar, J. and Sasek, A. (1970) Einflu $\beta$ der organischen und mineral-dungung auf die vertretung der eiweißfraktionen im weizenkorn. Getreide Mehl, 20, 27-29.

[28] Jahn-Deesbach, W. and Jürgens, U. (1973) Der einflu $\beta$ variierter stickstoffgaben auf die ertragsmorphologie und die stickstoffeinlagerung bei sommerweizen in einem gefaßversuch. IV. Mitteilung: Stickstoffeinlagerung in die verschiedenen proteinfraktionen des ganskornes und der einzelnen mehlfraktionen. Acker-und Pflanzenbau, 138, 276-286.

[29] Doekes, G.J. and Wennekes, L.M.J. (1982) Effect of nitrogen fertilization on quantity and composition of wheat flour protein. Cereal Chemistry, 59, 276-278.

[30] Pechanek, U., Karger, A., Gröger, S., Charvat, B., Schöggl, G. and Lelley, T. (1997) Effect of nitrogen fertilization on quantity of flour protein components, dough properties, and breadmaking quality of wheat. Cereal Chemistry, 74, 800-805. doi:10.1094/CCHEM.1997.74.6.800

[31] Johansson, E., Prieto-Linde, M.L. and Jonsson, J.O. (2001) Effects of wheat cultivar and nitrogen application on storage protein composition and breadmaking quality. Cereal Chemistry, 78, 19-25. doi:10.1094/CCHEM.2001.78.1.19

[32] MacRitchie, F. (1999) Wheat proteins: characterization and role in flour functionality. Cereal Foods World, 44, 188-193.

[33] Shewry, P.R. and A.S. Tatham, A.S. (1997) Disulphide bonds in wheat gluten proteins. Journal of Cereal Science, 25, 207-227. doi.org/10.1006/jcrs.1996.0100

[34] Wrigley, C.W. and Békés, F. (1999) Glutenin-protein formation during the continuum from anthesis to processing. Cereal Foods World, 38, 68-74.

[35] Zhang, P., He, Z., Zhang, Y., Xia, X., Chen, D. and Zhang, Y. (2008) Association between \% SDS-UPP (\% UPP) and end-use quality in Chinese bread wheat cultivars. Cereal Chemistry, 85, 696-700.

[36] Suchy, J., Lukow, O.M. and Ingelin, M.E. (2000) Dough microextensibility using a $2-\mathrm{g}$ mixograph and a texture analyzer. Cereal Chemistry, 77, 39-43. doi:10.1094/CCHEM.2000.77.1.39

[37] Anderssen, R.S., Bekés, F., Gras, P.W., Nikolov, A. and Wood, J.T. (2004) Wheat-flour dough extensibility as a discriminator for wheat varieties. Journal of Cereal Science, 39, 195-203. doi:10.1016/j.jcs.2003.10.002

[38] Bushuk, W. and Békés, F. (2002) Contribution of Protein to Flour Quality. In: Salgo, A., Tomoskozi, S. and Lasztity, R., Eds., Proc. Novel Raw Materials, Technologies and Products-New Challenge for the Quality Control. International Association for Cereal Science and Technol- 
ogy (ICC), Budapest, 14-19.

[39] Wrigley, C.W., Andrews, J.L., Bekes, F., Gras, P.W., Gupta, R.B., MacRitchie, F. and Skerrit, J.H. (1998) Protein-protein interactions-essential to dough rheology. In: Hamer, R.J. and Hoseney, R.C., Eds., Interactions: The Keys to Cereal Quality, The American Association of Cereal Chemists, St. Paul, 17-46.

[40] Lang, C.E., Lanning, S.P., Carlson, G.R., Kushnak, G.D., Bruckner, P.L. and Talbert, L.E. (1998) Relationship between baking quality and noodle quality in hard white spring wheat. Crop Science, 38, 823-827. doi:10.2135/cropsci1998.0011183X003800030034x

[41] Habernicht, D.K., Berg, J.E., Carlson, G.R., Wichman, D.M., Kushnak, G.D., Kephart, K.D., Martin, J.M. and Bruckner, P.L. (2002) Pan bread and raw Chinese noodle qualities in hard winter wheat genotypes grown in water-limited environments. Crop Science, 42, 1396-1403. doi: $10.2135 /$ cropsci2002.1396
[42] Souza, E.J., Martin, J.M., Guttieri, M.J., O’Brien, K.M., Habernicht, D.K., Lanning, S.P., McLean, R., Carlson, G.R. and Talbert, L.E. (2004) Influence of genotype, environment, and nitrogen management on spring wheat quality. Crop Science, 44, 425-42.

[43] Southan, M. and MacRitchie, F. (19999) Molecular weight distribution of wheat proteins. Cereal Chemistry, 76, 827-836.

[44] Uthayakumaran, S., Gras, P.W., Stoddard, F.L. and Bekés, F. (1999) Effect of varying the protein content and glutenin-to-gliadin ratio on the functional properties of wheat dough. Cereal Chemistry, 76, 389-394. doi:10.1094/CCHEM.1999.76.3.389

[45] Wieser, H. and Kieffer, R. (2001) Correlations of the amount of gluten protein types to technological properties of wheat flours determined on a micro-scale. Journal of Cereal Science, 34, 19-27. doi:10.1006/jers.2000.0385 